\title{
A triangular Eunotia (Bacillariophyceae) in southeastern Brazil: Eunotia trigona sp. nov.
}

\author{
André Fuhrmann ${ }^{1}$, Ditmar Metzeltin ${ }^{2}$ and Priscila Izabel Tremarin ${ }^{3,4}$
}

Received: 11 September, 2012. Accepted: 8 July, 2013

\begin{abstract}
We report a new diatom species for the Atlantic Forest of Brazil. The species, designated Eunotia trigona Fuhrmann, Metzeltin \& Tremarin sp. nov., is also new to science. It was found on moss in the Itatiaia mountain range in the state of São Paulo. Among the Eunotia taxa, E. trigona is distinguished by its unusual (perhaps unique) triangular-shaped valve, similar to those found in a few species of the genera Staurosira and Staurosirella.
\end{abstract}

Key words: Eunotiaceae, Itatiaia National Park, neotropics, South America

\section{Introduction}

The neotropical rain forests of southeastern Brazil present the oligotrophic and naturally acidic environments that particularly favor Eunotia Ehrenberg taxa (Round et al. 1990; Krammer \& Lange-Bertalot 1991; Necchi-Júnior et al. 2008). Metzeltin \& Lange-Bertalot (1998; 2007), Rumrich et al. (2000) and Metzeltin et al. (2005) collectively reported approximately 300 Eunotia taxa for South America, 93 of which were new to science. Resent studies have identified Eunotia taxa that are new to Brazil (Torgan \& Becker 1997; Burliga et al. 2007; Wetzel et al. 2010; Burliga \& Kociolek 2012) or specifically to the southeastern region of country (Metzeltin \& Tremarin 2011). In a recent study of the genus Eunotia, Lange-Bertalot et al. (2011) cautiously estimated the number of Eunotia taxa at "over 2000 " of which no more than 500 are expected to occur in the Holarctic. The bulk of the remaining 1500 taxa are expected to occur in the neotropics and paleotropics (Lange-Bertalot 2011, p. 15-20).

The Atlantic Forest covers the eastern slopes of the mountain ranges that run along the entire eastern (i.e., Atlantic) coastline of Brazil, roughly from the state of Rio Grande do Norte to the state of Rio Grande do Sul. Although intense human activity has reduced the extent of this biome to $8-12 \%$ of its original size (Morellato \& Haddad 2000; Metzger 2009), it persists in protected areas and is one of the world's leading hotspots of biodiversity, harboring many locally or regionally endemic species (Ribeiro et al. 2009). In fact, it appears that the species diversity is higher in the
Atlantic Forest than in most parts of the Amazon rain forest, the former reported to have an average endemism of 50\% (Metzger 2009). The diversity of the Atlantic Forest is due to a highly diverse array of environmental conditions: the region spans 29 degrees of latitude, extending from tropical to subtropical regions. Rainfall varies considerably from coastal ranges ( $4000 \mathrm{~mm} /$ year) to inland semideciduous forests $(1000 \mathrm{~mm} /$ year $)$, and elevations range from sea level to $>2000 \mathrm{~m}$ (Uzunian et al. 2008).

In the course of studying the diatom flora of the largest contiguous patch of the Atlantic Forest, the Serra do Mar, we identified a new Eunotia taxon, designated Eunotia trigona Fuhrmann, Metzeltin \& Tremarin sp. nov., which is easily identified under light microscopy (LM) by its remarkable triangular shape. This shape is probably unique within the genus. Here, we describe the new taxon and compare it with similar taxa.

\section{Material and methods}

The material was collected in March 2010 in the Itatiaia mountain range in southeastern Brazil, within the state of São Paulo, at an elevation of ca. $1100 \mathrm{~m}$. The taxon was encountered in dripping wet Sphagnum sp. growing thinly on an overhanging rock which shades the cave-like site constantly from direct sunlight; geodata are detailed below (locus typicus). Further samples were taken within an area of $2 \mathrm{~km}$ from the site. These included samples from lakes, rivers, rock pools, sphagnum, and the splash zones

\footnotetext{
${ }^{1}$ Goethe-University Frankfurt am Main, Frankfurt, Germany

${ }^{2}$ Institute for Ecology, Evolution, Diversity, Goethe-University Frankfurt am Main, Frankfurt, Germany

${ }^{3}$ Universidade Federal do Paraná, Departamento de Botânica, Curitiba, PR, Brazil

${ }^{4}$ Author for correspondence: ptremarin@gmail.com
} 
of waterfalls. Thus far, the taxon has been found only at the type locality.

The sphagnum containing the specimen was scraped off the rock with a spoon and rinsed with water from the site, the wash water being passed through a coarse sieve. The sample was cleaned by standard techniques: the material was first left to stand in 15\% hydrochloric acid (we observed no reaction to calcareous matter). Organic remnants were carbonised in hot concentrated sulphuric acid, to which potassium nitrite was added in small portions until the sample was reasonably clear. Colloidal clay was then dissolved in hydrogen peroxide with very dilute alkali added (sodium carbonate and sodium hexametaphosphate) and heated to just below the boiling point. Repeated decanting and centrifuging yielded clean material for study. Samples for LM were mounted in Zrax (a kind of Naphrax, with a refractive index $>1.7$;ttp://micrap.selfip.com:81/micrapp/media.htm). The LM studies were carried out using apochromatic lenses with a numerical aperture of 1.4 (Nikon, Tokyo, Japan; Carl Zeiss, Oberkochen, Germany), mounted on stands manufactured by Leitz (Wetzlar, Germany) and Zeiss. Photographs were taken with monochrome CCD-cameras (The Imaging Source, Charlotte, NC, USA). Samples on microfilter paper were mounted on stubs and sputter-coated with gold for inspection under scanning electron microscopy (SEM). All SEM observations were made on a Hitachi S-4500 (Hitachi, Tokyo, Japan). Images were adjusted for contrast and slightly sharpened in Adobe Photoshop.

\section{Results}

Eunotia trigona Fuhrmann, Metzeltin \& Tremarin sp. nov.

Fig. 1-29

Etymology: trigonus (Latin) - triangular.

Holotype Praep.: ZU8/39 - (Herbarium) Friedrich-HustedtZentrum fuer Diatomeenforschung Alfred-WegenerInstitut, Bremerhaven, Germany (code, BRM).

Isotypes Praep.: ZU8/40 - Friedrich-Hustedt-Zentrum fuer Diatomeenforschung, BRM; UPCB 73078 - Herbarium of Universidade Federal do Paraná, Curitiba, Brazil (code, UPCB); slide no. 6409 - Diatom Collection, Herbarium Alarich Rudolf Holger Schultz, Museu de Ciências Naturais, Fundação Zoobotânica do Rio Grande do Sul, Porto Alegre, Brazil (code, HAS).

Type locality: Itatiaia mountain range, southeastern Brazil, $250 \mathrm{~m}$ SW of the Véu da Noiva waterfall $\left(22^{\circ} 25^{\prime} 41.9^{\prime \prime}\right.$ 'S; $44^{\circ} 37^{\prime} 12.3^{\prime \prime}$ W; elevation, ca. 1100 m; leg. Fuhrmann March 2010; sample BR124; collector, Fuhrmann).

Description: cells solitary, no spines; valve forms a more or less regular triangle with the raphe side not generally

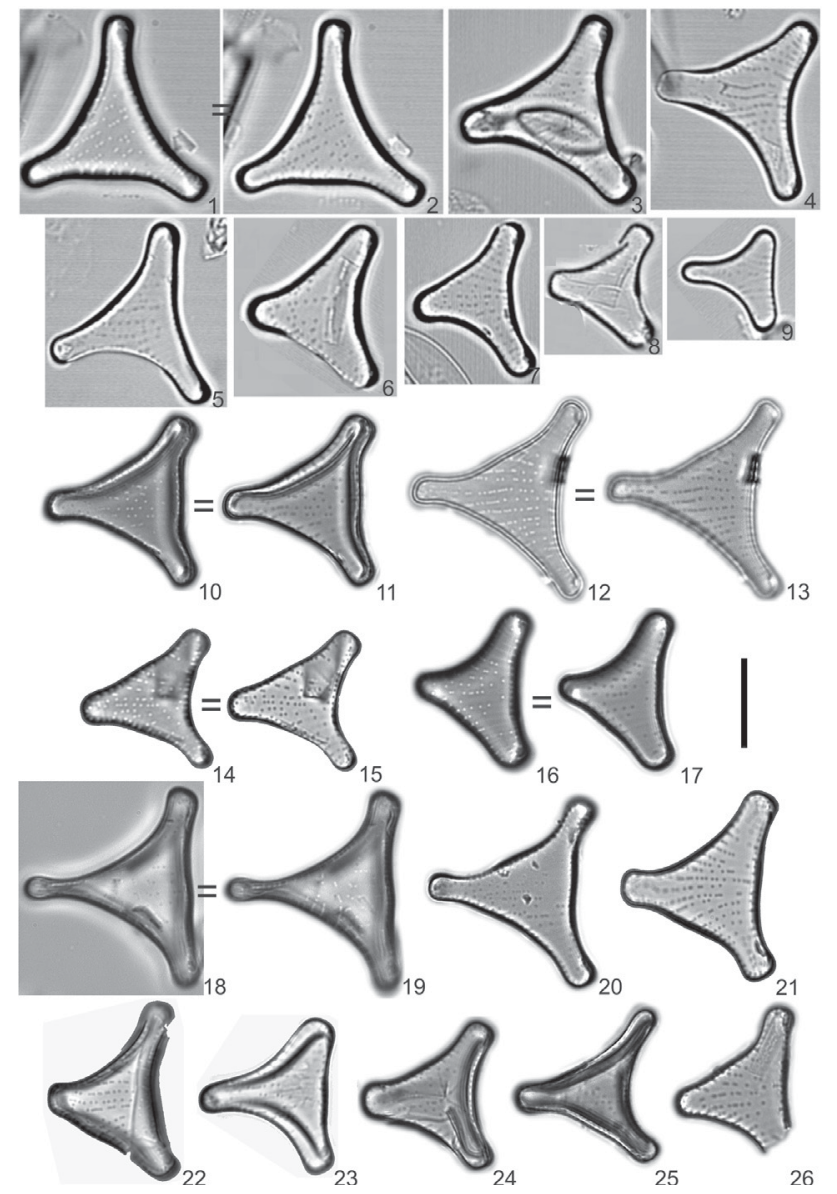

Figures 1-26. Photomicrographs of Eunotia trigona Fuhrmann, Metzeltin \& Tremarin sp. nov. under light microscopy. All specimens oriented as to have the raphe side on the right. Note striae always radiating from the raphe side. Scale: $10 \mu \mathrm{m}$.

distinguished by shape or size; sides concave; length, 11.6$22.9 \mu \mathrm{m}$; width, 10.2-18.8 $\mu \mathrm{m}$; apices moderately rostrate to subcapitate; striae perpendicular to margin the raphe side, slightly radiate towards the other sides, ca. 12 in $10 \mu \mathrm{m}$; punctae rounded, widely and irregularly spaced on the valve face and mantle, ca. $10-16$ in $10 \mu \mathrm{m}$; raphe approximately one third of valve length, distal ends short and curving into valve face; polar nodules delicate, but evident under LM; no rimoportula or cingulum bands observed.

Distribution: on dripping wet sphagnum growing on rock, not abundant; thus far, only at the type locality.

\section{Discussion}

Eunotia trigona has such a distinctive shape within its genus that there are no remotely similar known Eunotia taxa. The perfectly triangular valve shape does certainly not lie within the genetic variability of any known Eunotia species. The triangular-shaped valve is so unusual for the genus Eunotia that, on superficial examination, it may easily 


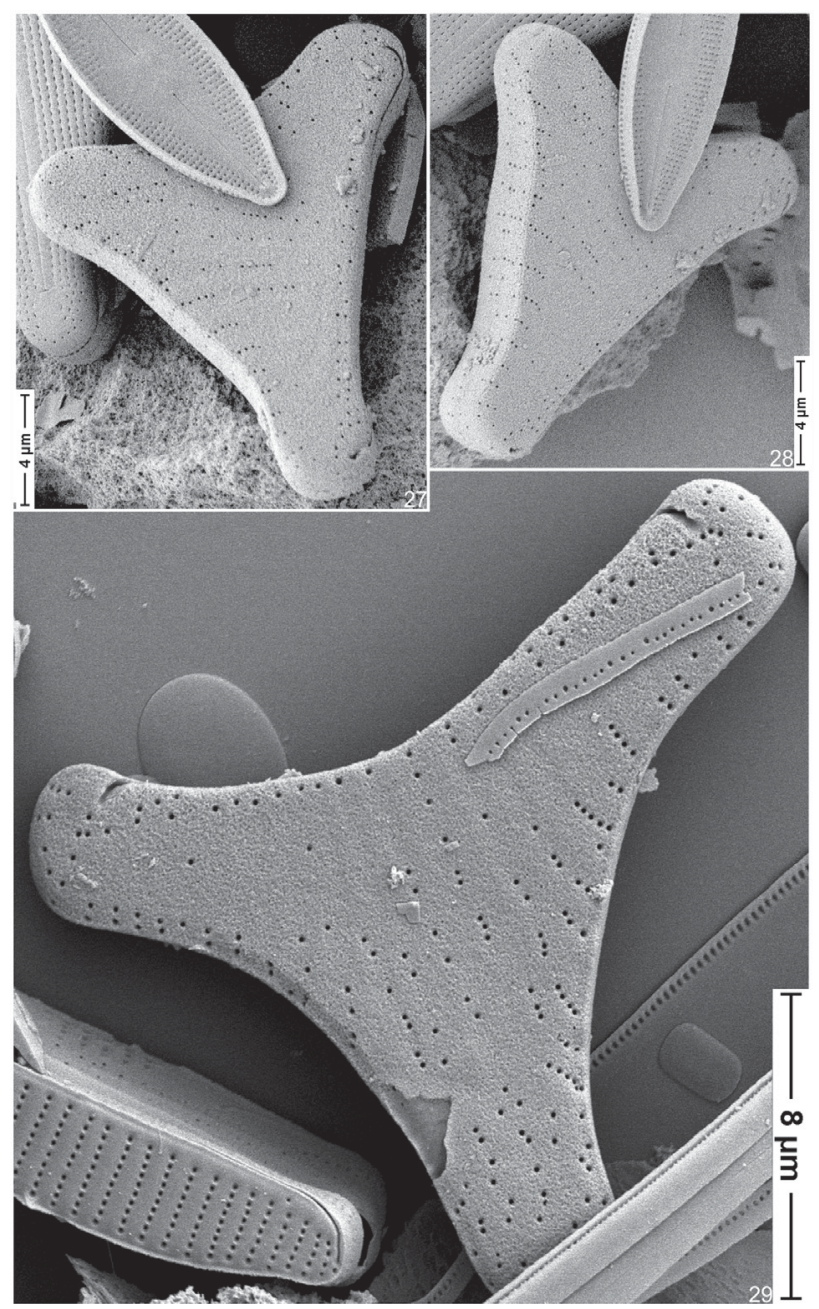

Figures 27-29. Photomicrographs of Eunotia trigona Fuhrmann, Metzeltin \& Tremarin sp. nov. under scanning electron microscopy, external view. Fig. 27 and 28: Overview of valve. Fig. 29: Note the striation pattern and the distal raphe ends.

be mistaken to belong to some other genus, such as the triangular forms formerly subsumed under Fragilaria; cf. e.g. Staurosirella pinnata var. trigona (Brun \& Héribaud) M. Aboal, Staurosira mercedes U. Rumrich, Lange-Bertalot \& M. Rumrich, Staurosira proboscoidea U. Rumrich, LangeBertalot \& M. Rumrich, Staurosira pseudoconstruens var. trigona Lange-Bertalot or Staurosira construens var. exigua (W. Smith) H. Kobayasi (Krammer \& Lange-Bertalot 1991; Rumrich et al. 2000). A closer look, however, reveals the presence of the characteristic Eunotia features: short raphe curving from a terminal nodule onto the valve face, which exhibits uniseriate striae.

The hypothesis that the found population has been generated by teratological deformation from a more familiarly shaped Eunotia taxon must be considered but does not stand up to scrutiny. We refer here to the cross-genera study of teratological deformation in Falasco et al. (2009a; 2009b) and Furey et al. (2009). First, there is no indication in the oligotrophic environment of any of the stress factors known to cause teratologies. Second, the population analyzed presented valve outline constant, not occurring asymmetry as one would expect in teratological deformation. Moreover, other features also affected by environmental stress as striae and puncta pattern as well as the raphe structure are regular in the way characteristic for Eunotia. Furthermore, no remotely similar deformations are known in the genus Eunotia. Moreover, the population does not occur in conjunction with a taxon that could plausibly be identified as the normal form. Each of these observations taken on its own would not suffice to dismiss the hypothesis of a teratological deformation. Taken together, however, the hypothesis must seem highly unlikely.

At the type locality, Eunotia trigona occurred in association with other Eunotia taxa: E. georgii Metzeltin \& Lange-Bertalot 1998; E. meridiana Metzeltin \& LangeBertalot 1998; E. paulovalida Metzeltin \& Lange-Bertalot 2007; E. rabenhorstii var. monodon Cleve \& Grunow in van Heurck 1881; E. tecta Krasske 1939; and Eunotia cf. valida Hustedt 1930. Other diatom genera present at the type locality included Cocconeis Ehrenberg, Brachysira Kützing, Diadesmis Kützing, Encyonema Kützing, Eolimna Lange-Bertalot \& Schiller, Fallacia Stickle \& Mann, Frustulia Rabenhorst, Gomphonema Ehrenberg, Kobayasiella LangeBertalot, Luticola Mann, Melosira C. Agardh, Navicula Bory de Saint-Vincent, Nitzschia Hassall, Nupela Vyverman \& Compere, Pinnularia Ehrenberg, Stenopterobia Brébisson ex Van Heurck and Surirella Turpin.

\section{Acknowledgments}

The first author acknowledges gratefully a travel stipend granted jointly by DAAD (Germany) and CAPES (Brazil). Thanks are also due to the Itatiaia National Park authorities for permission to take algae samples and to Manfred Ruppel for his keen eye and good humour at the SEM-laboratory of Goethe-University. Finally, we are indebted to two referees for their comments and suggestions.

\section{References}

Burliga, A.L. \& Kociolek, J.P. 2012. Four new Eunotia Ehrenberg species (Bacillariophyceae) from pristine regions of Carajás National Forest, Amazonia, Brazil. Nova Hedwigia 141: 53-70.

Burliga, A.L.M.; Torgan, L.C. \& Beaumord, A.C. 2007. Eunotia ariengae sp. nov., an epilithic diatom from Brazilian Amazon. Diatom Research 22: 247-253.

Falasco, E.; Bona, F.; Badino, G.; Hoffmann, L. \& Ector, L. 2009a. Diatom teratological forms and environmental alterations: a review. Hydrobiologia 623: 1-35.

Falasco, E.; Bona, F.; Ginepro, M.; Hlúbiková, D.; Hoffmann, L. \& Ector, L. 2009b. Morphological abnormalities of diatom silica walls in relation to heavy metal contamination and artificial growth conditions. Water SA 35(5): 595-606.

Furey, P.C.; Lowe, R.L. \& Johansen, J.R. 2009. Teratology in Eunotia taxa in the Great Smoky Mountains National Park and description of Eunotia macroglossa sp. nov., Diatom Research 24(2): 273-290. 
Krammer, K. \& Lange-Bertalot, H. 1991. Bacillariophyceae: Centrales, Fragilariaceae, Eunotiaceae. Pp. 576. In: Ettl, H.; Gerloff, J.; Heynig, H. \& Mollenhauer, D. (Eds.). Süsswasserflora Von Mitteleuropa. v. 2. Sttugart, Jena G. Fischer.

Lange-Bertalot, H.; Bak, M. \& Witkowski, A. 2011. Eunotia and some related genera. Pp. 747. In: Lange-Bertalot, H. (Ed.). Diatoms of Europe. v.6. Königstein, Koeltz Scientific Books.

Metzeltin, D. \& Lange-Bertalot, H. 1998. Tropical Diatoms of South America I: About 700 predominantly rarely known or new taxa representative of the neotropical flora. Pp. 695. In: Lange-Bertalot, H. (Ed.). Iconographia Diatomologica. v.5. Stuttgart, Koeltz Scientific Books. Metzeltin, D. \& Lange-Bertalot, H. 2007. Tropical Diatoms of South America II: Special Remarks on Biogeographic Disjunction. Pp. 877. In: Lange-Bertalot, H. (Ed.). Iconographia Diatomologica. v.18. Stuttgart, Koeltz Scientific Books.

Metzeltin, D. \& Tremarin, P. I. 2011. Uma nova espécie de Eunotia para o sudeste do Brasil: Eunotia fuhrmannii. Iheringia 62(2): 201-208.

Metzeltin, D.; Lange-Bertalot, H. \& García-Rodriguez, F. 2005. Diatoms of Uruguay. Pp. 736. In: Lange-Bertalot, H. (Ed.). Iconographia Diatomologica. v.15. Königstein, Koeltz Scientific Books.

Metzger, J.P. 2009. Conservation issues in the Brazilian Atlantic forest. Biological Conservation 142(6): 1138-1140.

Morellato, L.P.C. \& Haddad, C.F.B. 2000. Introduction: The Brazilian Atlantic Forest. Biotropica 32(4b): 786-792.
Necchi-Júnior, O.; Branco, L.H.Z. \& Spezamiglio, D.N. 2008. Distribuição ecológica de comunidades de macroalgas de ambientes lóticos do Parque Nacional de Itatiaia (RJ, MG) Brasil. Revista Brasileira de Botânica 31: 135-145.

Ribeiro, M.C.; Metzger, J.P.; Martensen, A.C.; Ponzoni, F.J. \& Hirota, M.M. 2009. The Brazilian Atlantic Forest: How much is left, and how is the remaining forest distributed? Implications for conservation. Biological Conservation 142(6): 1141-1153.

Round, F.E.; Crawford R.M. \& Mann, D.G. 1990. The diatoms. Biology and morphology of the genera. Cambridge, Cambridge University Press.

Rumrich, U.; Lange-Bertalot, H. \& Rumrich, M. 2000. Diatomeen der Anden.Von Venezuela bis Patagonien- Tierra del Fuego. In: Lange-Bertalot, H. (Ed.). Iconographia Diatomologica 9: 1-673.

Torgan, L.C. \& Becker, V. 1997. Eunotia densistriata sp. nov.: a subaerial diatom from Southern Brazil. Diatom Research 12: 115-124.

Uzunian, A.; Almeida-Cortez, J.A.; Cortez, P.H.M; Moraes, P.R. \& Franco, J.M.V. 2008. Coleção Biomas do Brasil - Mata Atlântica e Manguezais. São Paulo, HARBRA Ed.

Wetzel, C.E.; Ector, L.; Hoffmann, L. \& Bicudo, D.C. 2010. Colonial planktonic Eunotia (Bacillariophyceae) from Brazilian Amazon: taxonomy and biogeographical considerations on the E. asterionelloides species complex. Nova Hedwigia 90: 49-86. 